\title{
Editorial - TS: 49th meeting of the Brazilian dental materials group
}

\author{
Murilo Baena Lopes ${ }^{*}$ and Alcides Gonini Júnior
}

\author{
* Correspondence: \\ baenalopes@gmail.com \\ Department of Restorative Dentistry, \\ University of North Parana, Rua \\ Marselha, 183, Londrina PR \\ 86.046-230, Brazil
}

The Brazilian Group of Dental Materials (GBMD) was founded on 29th of September of 1965 and the 49th Meeting of the Group was held in Piracicaba during July 22-24, 2013. The conference was chaired by the Dental Material Group from the State University of Campinas. Approximately 220 papers were presented by researchers. The GBMD meetings have the objective to provide the researchers on the field a time to exchanged knowledge, present and discuss research results and techniques and to inspire the youth to follow the research carrier in dental materials. The importance of the GBMD meeting is also to reinforce the message that the engagement of all members is essential to the group success, which will result in a better dentistry.

This special issue of Applied Adhesion Science (AAS) contains selected papers presented at the meeting. Beside the member's presentations, invited guests presented meaningful courses: "Dilemmas in dental materials selection" by Prof. Richard Van Noort, "Organic synthesis associated to dental materials" by Prof. Fabrício Aulo Ogliari, "Why stress?" and "Using finite element analysis to improve oral health care" by Prof. Antheunis Versluis, "Non-thermal plasmas: Potential dental applications" by Prof. Nelson R.F.A. Silva, "Bioactive therapeutic approaches for minimally invasive restorative dentistry" by Prof. Salvatore Sauro, "Dental adhesive technology anno 2013. Modern adhesive approaches for durable bonding to tooth tissue and ceramics" by Prof. Bart Van Meerbeek, "Hydrolytic degradation of the resin restorative materials" by Prof. Eduardo Moreira da Silva and "Fatigue test and chewing simulation applied to ceramics" by Prof. Paulo Francisco César. In order to share the works presented at the conference, a selection of papers was made, which resulted in the present Special Issue. The papers involve the adhesion with the tooth structure and new experimental adhesives trying to improved the bond. This Issue is of great importance for GBMD as it consolidates the whole meeting once the outcomes become 36 available for the general scientific community.

\section{Acknowledgements}

We especially thanks Prof. Silvio de Barros, Editor-in-Chief of AAS who 37 made this Special Issue possible.

Received: 10 February 2014 Accepted: 10 February 2014

Published: 02 Jul 2014

$10.1186 / 2196-4351-2-19$

Cite this article as: Lopes and Gonini Júnior: Editorial - TS: 49th meeting of the Brazilian dental materials group. Applied Adhesion Science 2014, 2:19 